\title{
Studi Kasus Lingkungan Keluarga Di Desa Pejanggik : Pola Pembiasaan Pemecahan Masalah Bagi Anak Usia Dini
}

\author{
Ahmad Sanusi ${ }^{1}$, Muqowwim ${ }^{2}$, Erni Munastiwi ${ }^{3}$ \\ Universitas Islam Negeri Sunan Kalijaga ${ }^{1,2,3}$ \\ Email: aahmadsanusiii23@gmail.com ${ }^{1}$, muqowimkenzie@gmail.com ${ }^{2}$, \\ erni.munastiwi18@gmail.com ${ }^{3}$
}

\begin{abstract}
Abstrak
Membiasakan memecahkan masalah secara mandiri bagi anak merupakan hal yang sangat penting bagi kehidupannya. Sehingga dalam hal ini anak hendaknya diajarkan sedini mungkin agar anak terbiasa dalam menyikapi permasalahanpermasalahan yang dihadapinya. Adapun permasalahan-permasalahan yang biasa ditemukan dalam anak usia dini ialah seperti pemalu, tidak percaya diri, tidak bisa menahan emosinya seperti menangis dan marah-marah, dan tidak percaya diri terhadap potensinya. Dalam penelitian ini peneliti bertujuan untuk mencari tahu bagaimana pola atau strategi orangtua untuk membiasakan anak memecahkan masalah secara mandiri di lingkungan keluarga. Untuk mendapatkan hasil yang diharapkan dalam penelitian ini, peneliti menggunakan metode kualitatif dengan pendekatan studi kasus. Adapun Teknik pengumpulan data yang digunakan dalam penelitian ini ialah observasi, wawancara dan dokumentasi. Teknik analisis yang digunakan adala Teknik miles \& Hubberman Berdasarkan hasil penelitian yang dilakukan terkait dengan pola pembiasaan pemecahan masalah bagi anak usia dini dilingkungan keluarga peneliti dapat menemukan pola pembiasaan yang dilakukan oleh orangtua ataupun keluarga ialah 1) Memberikan anak rasa nyaman, 2) Mengetahui prinsip perkembangan anak, 3) Membangun komunikasi dengan baik, 4) Memberikan teladan, 5) Mengasah kemampuan anak, 6) Sering mengajak anak bermain, 7) Memberikan anak kebebasan atau tidak terlalu ikut campur.
\end{abstract}

\section{Kata kunci: Pembiasaan; Pemecahan Masalah; Anak Usia Dini; Keluarga.}

\section{Abstrak}

Getting used to solving problems independently for children is very important for their lives. So that in this case children should be taught as early as possible so that children are accustomed to addressing the problems they face. As for the problems that are commonly found in early childhood are like shy, not confident, unable to hold back his emotions such as crying and angry, and not confident in their potential. In this study, researchers aimed to find out how the patterns or strategies of parents to get children used to solving problems independently in the family environment. To get the expected results in this study, researchers used a qualitative method with a case study approach. The data collection techniques used in this study are observation, interviews and documentation. Analysis data used by Miles \& Hubberman. Based on the results of research conducted related

Studi Kasus Lingkungan (Sanusi; Muqowwim; Munastiwi) 201 
to the pattern of habitual problem solving for early childhood in the family environment researchers can find patterns of habituation carried out by parents or families are 1) Give children a sense of comfort, 2) Know the principles of child development, 3) Establish communication with good, 4) Give an example, 5) Sharpen children's abilities, 6) Give freedom not to interfere, 7) Give children freedom or not too meddle.

Keywords: Habituation; Solution to problem; Early childhood; Family.

\section{PENDAHULUAN}

Setiap individu sudah menjadi kodratnya untuk mendapatkan suatu permasalahan-permasalahan dalam kehidupannya. Permasalahan-permasalahan tersebut tidak hanya terjadi pada orang dewasa saja melainkan permasalahan sering juga terjadi pada kehidupan anak usia dini. Namun masalah yang terjadi pada anak usia dini tentunya tidak sama dengan orang dewasa. Oleh sebab itu diperlukan adanya suatu tindakan untuk mengajarkan anak dalam menghadapi permsalahan-permasalahan yang dialaminya agar anak mampu menyelesaikannya.

Aspek perkembangan kognitif merupakan aspek yang sangat fundamental dalam perkembangan anak usia dini dikarenakan dalam aspek ini terdapat poin penting bagi anak yang mencakup kemampuan memecahkan masalah-masalah sederhana yang sifatnya membangun keterampilan anak dalam berpikir logis, kritis, dan sistematis (Bahri: 2019). Hal ini juga dijelaskan sebagaimana yang dinyatakan pemerintah dalam Permendikbud Nomor 137 Tahun 2003 tentang standar isi pengembangan kognitif pada ayat 1 yang menyatakan bahwa (a) belajar dan pemecahan masalah, meliputi kemampuan dalam memecahkan masalah sederhana dalam kehidupannya sehari-hari dengan fleksibel dan dapat diterima lingkungan sekitarrya, (b) dapat berpikir logis, meliputi dapat membedakan sesuatu, pengkalsifikasian, pola-pola, mampu dalam memberikan inisiatif, menyusun sebuah rencana, dan dapat mengetahui sesuatu berdasarkan sebabakibat, dan (c) kemampuan berpikir simbolik, seperti kemampuan dalam mengenal, menyebutkan, dan menggunakan konsep serta huruf, kemudian mampu mempersentasikan berbagai benda dan gambar berdasarkan imajinasinya.

Adapun pemecahan masalah adalah suatu cara atau usaha yang dilakukan oleh setiap individu untuk mencari solusi dalam permasalahan-permasalahan yang dihadapi (Syaodih: 2018). Selain itu, Evans dalam Farida (2019) mengemukakan bahwa pemecahan masalah adalah suatu aktifitas yang berupaya untuk mencari jalan keluar atau jalan yang cocok dalam menghadapi masalah serta untuk mengubah kondisi yang sebelumnya menuju situasi kondisi sesuai dengan diharapkan. Dalam konteks anak usia dini pemecahan masalah merupakan kemampuan untuk memanfaatkan pengalaman maupun pengetahuannya dalam merumuskan hipotesis, mengumpulkan data, memiliki kemampuan dalam merancang serta membuat keputusan dalam merumuskan hipotesis, dan membuat hasil kesimpulan berdasarkan informasi yang mereka dapatkan dari proses-proses yang dijalankan secara ilmuah (Suryati: 2019). 
Menurut Paulia dalam Erma dkk, (2018) keterampilan pemecahan masalah merupakan kemampuan berfikir dalam mencari solusi untuk menyelsaikan suatu masalah dengan cara mengumpulkan fakta, menganalisis informasi, merancang alternatif pemecahan, dan memilih pemecahan masalah yang paling tepat. Keterampilan seperti ini merupakan salah satu elemen dari aspek perkembangan kognitif yang meliputi pemecahan masalah, pengambilan keputusan, berfikir kritis, dan berfikir kreatif. Adapun indikator dalam keterampilan pemecahan masalah pada anak usia dini ialah 1) keterampilan observasi/mengamati, 2) keterampilan mengumpulkan data dan informasi (colleting), 3) keterampilan mengolah informasi (comunicating), dan 4) keterampilan mengkomunikasikan informasi (Syaodih, dkk :2019).

Menurut Krulik dan Rudnik dalam Utami (2018) memperkenalkan dalam pemecahan masalah terdapat tahapan-tahapan yang disebut dengan heuristik. Heuristik merupakan suatu tahapan dalam menyelsaikan sebuah masalah dengan secara tidak berurutan. Pemecahan masalah heuristik dalam hal ini dibagi menjadi lima tahapan, diantaranya: Pertama, Read and Think yang mencakup kegiatan dalam mengidentifikasi fakta, pertanyaan, menggambarkan situasi, menjalaskan setting, dan menentukan langkah selanjutnya. Kedua, Explore and Plan meliputi kegiatan dalam mengorganisasikan informasi, mencari informasi yang tepat, mempersentasikan model masalah, serta dapat membuat diagram dan gambar. Ketiga, Select and Strategy meliputi kegiatan menemukan atau membuat pola, melakukan eksperimen, ekspansi, berbagi atau mengelompokan permasalahan menjadi lebih simpel, 4) Fimnd and Answer, mecakup kegiatan memprediksi dan kemampuan berhitung, dan (5) Replect and Extend, menelaah ulang jawaban, menentukan jalan keluar atau solusi lain, mengembangkan jawaban pada situasi lain, mendiskusikan jawaban dan menciptakan variasi masalah yang asal.

Membiasakan anak usia dini dalam mengajarkan memecahkan masalah begitu penting dalam kehidupannya dikarenakan dapat melatih anak untuk lebih analitis dalam mengolah informasi yang didapatkan kemudian mengajarkan anak mampu mengambil suatu keputusan dengan sendirinya. Sehingga dalam hal ini anak hendaknya diajarkan sedini mungkin dikarenkan sangat berkaitan dengan periode emas (golden age) yang dilalui anak. Periode ini seperti yang diketahui mulai dari anak sejak lahir sampai 6 tahun dan hanya berlangsung satu kali dalam kehidupannya. Pada tahap ini pula anak dirasa cepat menangkap, menyerap, dan memperoleh informasi.

Pentingnya membiasakan serta mengajarkan masalah bagi anak usia dini juga dijelaskan oleh Britz dalam Suryati (2019) bahwa pemecahan masalah merupakan landasan utama belajar pada anak usia dini, kemampuan anak dalam memecahkan masalah hendaknya terus dihargai, didorong, diberikan dukungan dikarenkan pemecahan masalah akan terjadi dalam kehidupan sehari-harinya. Lebih lanjut dikatakan bahwa pentingnya membiasakan anak usia dini dalam memecahkan masalah dapat melatih kemampuan anak dalam berfikir tentang diri sendirinya dan orang lain, serta dapat mendorong mereka untuk mengembangkan pemahaman dirinya ditengah masyarakat yang lebih luas. 
Kemampuan pemecahan masalah anak memerlukan perhatian yang lebih karena kelemahan serta ketidakmampuannya yang muncul pada diri anak akan berdampak ketika telah memasuki jenjang pendidikan berikutnya maupun ketika anak sudah semakin bertambah usianya yang ujungnya berakhir pada ketidakmampuan anak dalam menerjemahkan masalah yang dihadapi untuk diselesaikan. Oleh sebab itu penting dilakukan suatu hal yang dapat membiasakan anak untuk terampil dalam memecahkan permasalahan-permasalahan yang dihadapinya. Pembiasaan ini tentunya menjadi tugas dan tanggung jawab bagi pendidik dan terutama bagi orang tua ataupun keluarga anak. Hal ini dikarenkan bahwa orangtua merupakan pendidik yang pertama serta orang yang sering berinteraksi dengan anak. Apabila orang tua ataupun keluarga terbiasa membiasakan dan mengajarkan anak memecahkan masalah sejak dini tentu dalam diri anak akan tertanam suatu kebiasaan atau semacam adat yang dimana nantinya ketika menemukan suatu masalah anak tersebut mampu menyelsaikannya. Hal ini sebagaimana yang dikatakan Syarbini dalam Nurul (2018) bahwa melakukan pembiasaan kepada anak sejak dini akan membuat anak menjadi terbiasa dan kebiasaan tersebut menjadi semacam adat yang sudah melekat dalam diri pribadi anak tersebut sehingga akan menjadi sebuah bagian yang tidak terpisahkan dalam kehidupanya. Begitupun juga pada membiasakan anak dalam hal memecahkan masalah secara mandiri agar anak terampil dalam menghadapinya.

Menurut Baumrind dalam Jamiatul (2020) mengatakan bahwa terdapat beberapa model pola asuh orang tua dalam membimbing anak diantaranya yaitu pola asuh otoriter, pola asuh demokrasi, dan pola asuh permisif. Adapun pola asuh otoriter merupakan pola yang dilakukan oleh orangtua dalam membentuk, mengontrol dan mengevaluasi prilaku anak. segala ucapan ataupun perkataan serta kehendak orangtua dijadikan sebuah peraturan yang harus ditaati oleh seorang anak. Dalam pola ini tidak sedikit orangtua yang menerapkan hukuman bagi anaknya agar anak taat terhadap keinginan orangtuanya. Selanjutnya pola asuh demokratis, pola ini merupakan pola yang dilakukan oleh orangtua yang ditandai dengan keharmonisan dalam mendidik anak seperti orangtua lebih memberikan sebuah pengakuan kepada kemampuan anaknya, anak diberikan kepercayaan serta diberikan luang untik bereksplorasi. Dan yang terakhir pola asuh permisif ialah pola asuh yang ditandai dengan cara orang tua mendidik anak dengan memberikan nak kebebasan yang cukup bebas, orangtua menganggap anaknya layaknya seperti orang dewasa atau muda dan diberikan kelonggaran dalam melakukan keinginannya, kontrol orangtua terhadap anaknya sangat lemah dan kurang (Yulianti: 2017).

Adapun peneilitian terkait pemecahan masalah anak sebenarnya sudah banyak yang telah melakukan penelitian sebelumnya. Salah satu diantaranya ialah Maretha Masyah dkk, dengan judul "Meningkatkan Kemampuan Pemecahan Masalah Melalui Bermain Tebak Gambar Pada Anak Kelompok A1 di PAUD Kemala Bhayangkari Bengkulu Utama”. Selain itu juga Erma Widiastuti, dkk dengan judul "Pengaruh Pendekatan Saintifik Terhadap Kemampuan Pemecahan Masalah Pada Anak Kelompok B di Taman Kanak-kanak”. Kedua penelitian 
tersebut sama-sama mengkaji terkait dengan pemecahan masalah anak, namun lebih membahas pada bagaimana cara mengajarkan anak dalam hal memecahkan masalah secara mandiri dengan menggunakan berbagai metode pembelajaran. Hal itu menurut peneliti lebih cendrung mengajarkan anak pada lingkup sekolah saja namun mengabaikan bagaimana peran orang tua dan keluarga dilingkungan rumahnya. Maka pada artikel kali ini peneliti akan lebih memfokuskan pada pola pembiasaan pemecahan masalah anak usia dini dilingkungan keluarga.

Berdasarkan pengamatan diatas maka tujuan daripada penelitian ini ialah untuk mengetahui usaha yang dilakukan orang tua atau keluarga dalam pembiasaan memecahkan masalah anak usia dini dilingkungan keluarga, sebagai suatu proses pembiasaan yang meliputi strategi orangtua dalam membiasakan anak dalam memecahkan masalah di kehidupannya agar supaya mereka terbiasa dalam memecahkan masalah serta menyelsaikannya secara mandiri. Maka fokus permasalahan yang dikaji ialah untuk mengetahui bagaimana pola dan strategi orang tua ataupun keluarga dalam membiasakan anak terampil memecahkan masalahnya secara mandiri dilingkungan keluarga.

\section{METODE PENELITIAN}

Penelitian yang digunakan dalam penelitian ini adalah pendekatan kualitatif. Sugiono (2016:17) mengatakan bahwa penelitian kualitatif adalah penelitian yang digunakan untuk meneliti suatu kondisi objek alamiah yang menjadikan peneliti sebagai instrumen kunci. Adapun jenis penelitian yang digunakan adalah penelitian studi kasus. Penelitian studi kasus adalah suatu jenis penelitian kualitatif yang dilakukan dengan cara mengeksplorasi suatu kegiatan, peristiwa-peristiwa, proses, serta aktivitas yang dilakukan terhadap individu atas komunitas secara intens, detail, dan mendalam (Creswell, 250:2016) Penelitian ini dilaksanakan di desa Pejanggik Kecamatan Praya Tengah Kabupaten Lombok tengah, NTB. Teknik pengumpulan data yang dilakukan dalam penelitian ini adalah wawancara, observasi, dan dokumentasi. Teknik analisis data yang diggunakan ialah model interaktif dari Miles and Huberman untuk menganalisis data-data yang ditemukan oleh peneliti. Penelitian ini menggunakan triangulasi untuk menguji keabsahan data yang didapatkan. Teknik triangulasi data yang peneliti gunakan ialah Teknik triangulasi dan sumber data melalui literatur, catatan wawancara, catatan lapangan, catatan dokumentasi serta dari berbagai sumber. Sampel peneliatian dalam penelitian ini ialah orang tua atau keluarga yang memiliki anak usia dini 4-6 tahun yang sekolah pada jenjang PAUD di desa Pejanggik sebanyak 20 orangtua atau keluarga.

\section{HASIL DAN PEMBAHASAN}

Berdasarkan hasil penelitian yang dilaksanakan oleh peneliti kepada seluuruh informan terkait dengan pola pembiasaan dalam mendidik anak untuk mampu memecahkan masalah secara mandiri, orang tua ataupun keluarga melakukannya dengan berbagai cara diantaranya (1) Memberikan anak rasa nyaman, (2) Mengetahui prinsip perkembangan anak, (3) Membangun komunikasi 
dengan baik, (4) Memberikan teladan, (5) Mengasah kemampuan anak, (6) Sering mangajak anak bermain, (7) Memberikan anak kebebasan atau tidak terlalu ikut campur.

\section{Memberikan Anak Rasa Nyaman}

Perasaan aman merupakan kebutuhan yang amat penting bagi pertumbuhan dan perkembangan anak. Berdasarkan hasil wawancara oleh Ibu NH (30) mengatakan bahwa dalam mengasuh anak hendaknya orang tua untuk selalu memberikan rasa aman terhadap anak agar anak mampu dengan tenang dalam menyikapi permasalahan-permasalahan yang dihadapi oleh anak itu sendiri. Selain itu Ibu F (28) juga mengemukakan bahwa memberikan rasa aman terhadap anak akan sangat membantu terhadap pertumbuhan dan perkembangan mereka. Hal ini sebagaiamana yang dinyatakan oleh Asti (2017) dalam hasil penelitiannya bahwa memberikan rasa aman terhadap anak akan berdampak pada proses pembelajaran serta pertumbuhannya dengan pesat.

Strategi membiasakan anak dalam memecahkan masalah secara mandiri tidak bisa mengesampingkan pentingnya rasa aman bagi seorang anak. Pasalnya rasa aman ini akan sangat berdampak terhadap kondisi anak tersebut. Berdasarkan hasil wawancara dengan Bapak AB (36) mengatakan bahwa memberikan rasa aman kepada anak dapat dilakukan dengan berbagai cara diantaranya memberikan tempat yang nyaman, kondisi yang kondusif, memberikan kasih sayang, memenuhi kebutuhannya, meluangkan waktu yang penuh kepada anak dalam kesehariannya. Apabila kondisi anak tersebut dalam kedaan tenang, damai, dan nyaman maka anak akan lebih cepat menyelsaikan permasalahan yang ia hadapi, begitupun sebaliknya anak akan lebih mudah bosan, marah, malas jika kondisi atau keadaannya tidak nyaman.

Menurut Holis (2016) dalam mendidik anak dilingkungan keluarga orangtua hendaknya memiliki tiga ciri yang harus dipahami diantaranya, pertama, keluarga memberikan suasana kondusif terhadap emosional anak, misalnya memberikan perasaan bahagia, rasa aman, disayangi, dan dilindungi. Kedua, mengenal dasar-dasar kependidikan, seperti tugas dan peran orangtua terhadap anak. ketiga, berkerjasama dengan lembaga pendidikan tempat anak menjalani pendidikan. Oleh sebab itu menurut informan Ibu MS (30) penting bagi orangtua ataupun keluarga untuk selalu memperhatikan kondisi anak dengan selalu memberikan rasa nyaman terhadapnya. Pendapat ini sejalan dengan hasil penelitian yang dilakukan oleh Chasiyah, dkk dalam Afisyah (2019) bahwa orangtua ataupun keluarga memiliki peran dan tugas yang sangat urgen bagi pertumbuhan dan perkembangan anak yaitu untuk selalu memberikan rasa dimiliki, memberikan rasa aman, kasih sayang serta mengembangkan hubungan yang harmonis serta ketenangan dalam kehidupan dikeluarga.

\section{Mengetahui Prinsip Perkembangan Anak}

Proses mendidik anak usia dini hendaknya dilaksanakan dengan berorientasi pada pemberian makna bagi anak melalui pengalaman yang sifatnya 
konkrit atau nyata. Pengalaman nyata dalam hal ini memungkinkan anak menunjukan aktifitas dan rasa ingin tahu secara optimal dan menempatkan posisi oarangtua ataupun keluarga untuk menjadikan diri sebagai pendamping serta fasilitator yang selalu dekat dengan anak dalam berbagai kegiatannya.

Dalam mendidik anak ada beberapa prinsip yang perlu diperhatikan dalam mengasuh serta membimbing anak yaitu memahami tahapan perkembangan anak. Orang tua ataupun keluarga harus mampu memilah dan memilih berbagai kegiatan-kegiatan yang dilakukan oleh seorang anak jangan sampai terlalu sulit untuk dipahami. Berdasarkan hasil wawancara yang didapatkan dari bapak B (40) menyatakan bahwa dalam membimbing anak hendaknya orang tua atau keluarga untuk memperhatikan tahapan perkembangan anak suapaya anak tidak merasa kesulitan termasuk membiasakan anak dalam memecahkan masalah secara mandiri. Hal senada juga dikatakan oleh salah satu informan Ibu H (25) yang mengatakan bahwa untuk membiasakan anak terbiasa dalam menyikapi permasalahan-permasalahan yang dialami hendaknya orang tua juga harus memahami tahap-tahap perkembangan mereka, Lebih lenjut Ibu M (27) menyatakan pada saat anak usia dini orang tua harus mampu memahami bahwa kegiatan-kegiatan yang sifatnya pembelajaran dilakukan berdasarkan perkembangan dan kebutuhan anak. Hal ini juga disampaikan oleh Aip Saripudin (2019) dalam mendidik anak ada beberapa prinsip yang mesti diperhatikan dalam mengasuh serta membimbing anak yaitu berorientasi pada perkembangan anak, kemudian kebutuhan anak, memberikan lingkungan yang kondusif, menyenangkan anak dengan memanfaatkan berbagai media dan sumber belajar yang ada.

Membimbing anak saat masih usia dini harus dilakukan dengan sangat teliti dan berhati-hati dikarenakan anak usia dini merupakan individu yang unik, oleh sebab itu perlu memperhatikan apa saja kegiatan-kegiatan yang dilakukan oleh anak tersebut berdasarkan tahapan perkembangan anak. Tingkat perkembangan anak merupakan suatu hal yang fundamental untuk diperhatikan oleh orangtua ataupun keluarga. Memahami perkembangan anak dengan secara maksimal akan membantu anak dalam kehidpannya. Oleh karenanya hal yang terpenting dilakukan oleh orangtua ataupun keluarga adalah menyimak tahapan perkembangan anak serta aspek-aspek perkembangan anak. Adapun aspek-aspek perkembangan anak usia dini ialah aspek perkembangan agama dan moral, fisikmotorik, kognitif, sosial emosional, aspek bahasa dan seni (Suyadi \& Muliyadi, $58: 2013)$.

Dalam hal membiasakan anak terampil memecahkan masalah secara mandiri sangat erat kaitanya dengan aspek perkembangan kognitif. Aspek perkembangan kognitif dalam hal ini meliputi kemampuan memcahkan masalahmasalah sederhana dalam kehidupan sehari-seharinya dengan cara mudah dan fleksibel serta kemapuan seorang dalam mengaplikasikan pengetahuan dan pengalamannya dalam kehidupannya (Bahri: 2019). Hal ini juga dijelaskan sebagaimana yang dinyatakan pemerintah dalam Permendikbud Nomor 137 Tahun 2003 tentang standar isi pengembangan kognitif pada ayat 1 yang 
menyatakan bahwa (a) belajar dan pemecahan masalah, meliputi kemampuan dalam memecahkan masalah sederhana dalam kehidupannya sehari-hari dengan carafleksibel dan dapat diterima lingkungan sekitarrya, (b) dapat berpikir logis, meliputi dapat membedakan sesuatu, pengkalsifikasian, pola-pola, mampu dalam memberikan inisiatif, menyusun sebuah rencana, dan dapat mengetahui sesuatu berdasarkan sebab-akibat, dan (c) kemampuan berpikir simbolik, meliputi kemampuan dalam mengenal, menyebutkan, dan menggunakan konsep serta huruf, serta mampu mempersentasikan berbagai benda dan gambar berdasarkan imajinasinasinya.

\section{Membangun Komunikasi Dengan Baik}

Komunikasi di dalam keluarga merupakan alat atau media dalam membangun hubungan yang harmonis serta erat dengan sesama anggota keluarga, karena itu komunikasi berperan penting dalam membangun interaksi orang tua dan anak (Mariana, dkk: 2017). Ibu D (28) mengemukakan bahwa komunikasi yang baik antara anak dan orangtua merupakan suatu keawajiban dikarenakan dapat membantu perkembangan anak termasuk dalam kepribadian anak dan rasa percaya dirinya. Adapun komunikasi adalah suatu pentransferan informasi maupun pesan oleh seseorang kepada orang lain untuk memberitahu informasi atau untuk mengubah sikap, pendapat, dan prilaku dengan secara langsung ataupun tidak langsung (Diana, dkk: 2017).

Komunikasi dalam hal ini memiliki peranan yang amat penting dalam kehidupan keluarga salah satunya adalah seorang anak. Komunikasi orang tua dengan anak diharapkan terjadi adanya sebuah interaksi, saling tukar pikiran, pendapat, dan pengalaman. Berdasarkan hasil wawancara oleh Ibu R (29) komunikasi yang baik dan efektif antara orangtua dan anak akan sangat berpengaruh dalam pertumbuhan dan perkembangan anak dikarenakan dapat membentuk kepercayaan diri dan kemandirian anak.

Adapun menurut Ibu IO (36) mengatakan berdasarkan hasil penelitian yang dilakukan peneliti bahwa komunikasi yang bisa dilakukan oleh orangtua ataupun keluarga dengan anak tidak hanya sebatas ucapan semata namun lebih kepada bagaimana memberikan anak kenyamanan dalam melakukan segala aktivitas seperti halnya mendukung, memberikan kasih sayang dan sebagainya. Hal senada disampaikan Bahri (2018) berdasarkan hasil penelitiannya yang menyatakan bahwa komunikasi yang dibangun antara oangtua dan anak tidak hanya komunikasi verbal saja melainkan juga komunikasi non verbal seperti pelukan, ciuman, sentuhan yang nantinya sangat berpengaruh dalam kehidupan anak.

Selain itu menurut Endang (2018) bahwa komunikasi orangtua dengan anak bisa dilakukan dengan dua cara diantaranya ialah: pertama, komunikasi satu arah, dalam komunikasi ini orangtua ataupun keluarga bisa menyampaikan pesanpesan yang sifatnya memberikan motivasi, dorongan kepada anak namun secara universal tanpa menghakiminya. Kedua, komunikasi dua arah, komunikasi ini 
dilakukan oleh orangtua ataupun keluarga dengan melibatkan anak untuk saling menyampaiakan pemikiran, bertukar pikiran, menyampaiakan perasaan, informasi, saran ataupun nasehat-nasehat sehingga akan memberikan rasa nyaman terhadap anak, menimbulkan kesenangan yang berpengaruh terhadap sikap positif anak dalam menjalin hubungan dengan orangtua ataupun keluarga. Komunikasi yang seperti ini tentunya terbangun berkat adanya suatu keterbukaan antara orang tua dan anak, kemudian dukungan, empati serta kesamaan persepsi antara keduanya. Apabila hal ini sudah terjadi maka akan mudah bagi orangtua ataupun keluarga untuk membiasakan anak mandiri dalam memecahkan masalah melalui komunikasi yang terjalin dengan baik.

\section{Memberikan Teladan}

Memberi contoh merupakan salah satu cara yang paling penting bagi orangtua ataupun keluarga dalam mendidik anak. Dalam kehidupan dirumah hendaknya orangtua untuk selalu memberikan contoh atau teladan yang baik agar anak dapat menerima serta mengikuti apa saja yang diberikan oleh orangtua ataupun keluarga dalam kehidupannya sehari-hari baik dengan tindakan maupun ucapan. Keluarga dalam hal ini tentunya memiliki peran yang sangat strategis dalam membentuk kepribadian anak termasuk dalam mengajarkan atau membiasakan anak untuk terampil dalam memecahkan masalah secara mandiri. Menurut salah satu informan bapak A (35) mengemukakan bahwa menjadi orangtua tentunya memiliki peran yang sangat penting dalam perkembangan anak. Oleh sebab itu selaku orangtua hendaknya untuk selalu memberikan teladan yang baik kepada anak agar anak mampu meniru apa yang kita kerjakan termasuk dalam hal mengajarkan anak untuk bersikap mandiri. Selain itu menurut ibu IS (42) mengatakan dalam mengajarkan anak untuk bersikap mandiri termasuk dala $\mathrm{m}$ membiasakan anak memecahkan masalahnya hendaknya selaku orangtua memberikan contoh bagaimana bersikap mandiri dengan mengajarkan melalui tindakan serta ucapan. Hal ini juga dikatakan Rahayu (2018) menurutnya keluarga merupakan lingkungan yang sangat erat dengan anak, keluarga memiliki tugas dan peran yang sangat penting dalam medukung dan mendorong proses perkembangan anak secara optimal. Lebih lanjut Azizah (2017) mengatakan bahwa keluarga merupakan tempat paling berpengaruh dalam kehidupan anak dikarenakan di kuluargalah anak mendapatkan pendidikan pertama dan utama, dimana kepribadian anak akan dibentuk pertama kali dalam lingkungan keluarga.

Memberikan teladan kepada anak tentunya akan sangat berdampak bagi kehidupan anak dikarenakan pada masa anak usia dini anak merupakan peniru ulung, ia akan senantiasa dan sangat mudah meniru sesuatu yang ia lihat. Lebihlebih anak akan lebih mudah meniru dan mengikuti sesuatu yang sifatnya baru dan belum dikenalnya baik itu prilaku ataupun ucapan. Apabila orangtua ataupun keluarga mampu memberikan contoh atau teladan yang baik maka secara langsung anak akan mempu menyerap serta mengaplikasikan dalam kehidupannya berdasarkan apa saja yang mereka lihat dan rasakan dilingkungan keluarganya. Demikian sebaliknya. Hal ini juga dikatakan Novrida dkk (2017) bahwa segala 
tingkah laku maupun perkembangan anak pastinya akan mencontoh pada kedua orangtuanya.

Oleh sebab itu salah satu informan dalam penelitian ini Ibu MR (25) mengatakan bahwa penting bagi kedua orang tua maupun seluruh anggota keluarga untuk memberikan penddikan kepada seorang anak yang mengarah kepada pengembangan potensi anak serta untuk mengajarkan anak mandiri dalam kehidupannya termasuk dalam membiasakannya dalam menyelsaikan ataupun memecahkan masalahnya. Hal ini menurutnya dapat dilakukan dengan memberikan pelajaran yang baik dalam proses perkembangannya dan terus menerus untuk mendorong, membimbing, memotivasi dan mengajarkan anak untuk mandiri dalam menghadapi persoalan dalam kehidupannya.

\section{Mengasah Kemampuan Anak}

Dalam membiasakan anak untuk memecahkan masalahnya secara mandiri orangtua-orangtua yang menjadi informan pada penelitian ini salah satunya ibu ISH (30) mengatakan bahwa hal yang perlu dilakukan ialah mengasah kemampuan anak. Menurutnya keterlibatan orangtua dalam mengasah kemampuan anak sangat penting. Sebagaimana telah disampaikan sebelumnya bahwa orangtua merupakan guru pertama dan utama yang akan mengajar serta membimbing anak dalam proses perkembangannya. Orang tua memiliki peran yang sangat strategis dalam pendidikan anak. Sebagaimana yang dikatakan Mukti (2015) bahwa tugas seorang orang tua terhadap anak selain sebagai guru pertama bagi anak-anaknya juga sebagai tempat anak belajar kehidupan serta belajar dalam mengembangkan potensi yang dimiliki anak, sebagai pelindung bagi anak, sebagai tempat bergantung anak, sumber bagi kehidupan anak dan sumber kebahagiaan anak. AD (28) mengatakan untuk mengasah kemampuan anak orangtua bisa melakukan dengan sering terlibat dalam keseharian anak dirumah, misalnya orangtua membantu mengejarkan PR, melakukan kegiatan-kegiatan yang sifatnya menumbuhkan kreativitas anak dan mengajarkan anak bersosial dilingkungan keluarga dan sekitarnya. Selain itu P (32) mengatakan bahwa dalam mengasah kemampuan anak termasuk pada membiasakan anak terampil dalam memecahkan masalah secara mandiri orangtua hendaknya selalu mendorong anak untuk berlaku mandiri seperti membolehkan anak mengambil keputusan sendiri, sering terlibat dalam kehidupan anak seperti bermain, belajar, dan pada kegiatankegiatan yang lainnya. Menurut (Mukti: 2015) ada beberapa hal yang dapat dilakukan oleh orang tua dalam mengasah kemampuan anak serta menunjang potensi anak diantaranya ialah (1) menghargai pendapat anak dan mendukungnya untuk bisa mempersentasikannya, (2) memberikan keluangan waktu kepada anak untuk berpikir, merenung dan berkhayal, (3) memberikan kebebasan anak dalam mengambil keputusan sendiri, (3) menghargai apa yang menjadi karya anak, (4) mendorong anak untuk selalu bertanya, (5) memberikan anak kegiatan-kegiatan yang positif, (6) menikmati keberadaan bersama anak, (7) memberikan dukungan serta reward kepada anak, (8) mengajarkan anak untuk berkerja secara mandiri, dan (9) menjalin hubungan dan kerjasama yang baik dengan anaknva. 


\section{Sering Mengajak Anak Bermain}

Bermain merupakan hal yang amat penting bagi perkembangan anak usia dini dikarenakan dunia anak dikenal dengan dunia bermain. Piaget dalam Yuhasriati \& Dewi (2016) menjelaskan bahwa bermain merupakan suatu aktifitas yang dilakukan secara terus-menerus dan akan memunculkan kebahagiaan dan kepuasan tersendiri bagi seseorang. Dengan bermain, anak-anak menggunakan bagian tubuhnya seperti otot-ototnya, meransang bagian-bagian tubuhnya, mengeksplorasi dunia sekitarnya, mengenali lingkungan tempat ia tinggal dan mengenl seperti apa diri mereka sendiri (Musbikin: 77:2010). Selain itu, latif dkk (77:2014) mengatakan bahwa dengan bermain anak dapat belajar, artinya bahwa anak yang belajar adalah anak yang bermain, dan begitupun sebaliknya anak yang bermain adalah anak yang belajar.

Adapun manfaat dari bermain ialah dapat mengembangkan aspek-aspek perkembangan yang dimiliki oleh seorang anak seperti aspek kognitif, moral, motorik, bahasa, seni serta keterampilan sosial. Dalam perkembangan aspek kognitif seperti yang diketahui bahwasanya terdapat beberapa aspek yang menjadi fokusnya seperti yang dijelaslan dalam dalam Standar Tingkat Pencapaian Perkembangan Anak (STPPA) pada Permendikbud 137 tahun 2014 meliputi kemampuan memecahkan masalah-masalah secara sederhana (Ayu \& Rimpiati: 2018).

Selain itu informan ibu NR (30) yang mengatakan bahwa mengajarkan anak dapat dilakukan dengan sering-sering mengajak anak untuk bermain, menurutnya selain dapat mengembangkan kreativitasnya anak juga akan lebih senang apabila melakukan suatu hal dengan kegiatan bermain. Menurutnya permainan bisa dilakuakan dengan menggunakan media ataupun alat yang ada disekitar anak serta bisa dilakukan untuk melatih kemampuan anak dalam membiasakan diri menyelsaikan persoalan-persoalan yang dihadapi.

Menurut salah satu informan dalam penelitian ini yakni bapak AS (28) mengatakan bahwa bermain merupakan suatu kegiatan yang dilakukan oleh seorang anak yang dapat membuatnya senang berdasarkan dunianya sendiri. Hal senada juga dikatakan oleh bapak B (36) selaku informan dalam penelitian ini yang mengatakan bahwa mengajarkan anak dapat dilakukan dengan seringsering mengajak anak untuk bermain, menurutnya selain dapat mengembangkan kreativitasnya anak juga akan lebih senang apabila melakukan suatu hal dengan kegiatan bermain. Menurutnya permainan bisa dilakuakan dengan menggunakan media ataupun alat yang ada disekitar anak serta bisa dilakukan untuk melatih kemampuannya dalam membiasakan diri menyelsaikan persoalan-persoalan yang dihadapi.

Lebih lanjut Ibu PT (25) mengatakan bahwa berdasarkan pengalaman yang dirasakan selama mengasuh anak bermain memunyai manfaat yang begitu banyak bagi perkembangan anak salah satunya ialah anak merasa lebih senang dan bahagia, kemudian anak terlihat lebih sehat dan lincah dikarenakan 
kegiatannya berkaitan dengan anggota tubuhnya, selain itu dapat melatih daya kreativitasnya. Sebagaimana manfaat bermain yang dirasakan oleh salah satu informan tersebut. Hal yang sama juga dijelaskan oleh Latif dalam Utami (2019) bahwa terdapat beberapa manfaat bermain bagi anak usia dini ialah mengembangan aspek-aspek perkembangan ank diantaranya 1) aspek perkembangan fisik yakni anak melakukan aktifitas yang melibatkan pergerakanpergerkan tubuh yang mengakibatkan tubuh anak jadi lebih kuat, 2) aspek perkembangan sosial emosional yakni, anak merasa bahagia karena memiliki banyak teman, 3) aspek kognitif yakni mampu belajar dengan memanfaatkan benda-benda maupun objek-objek yang ada disekitarnnya, 4) aspek seni yakni, kemampuan dan kepekaan anak dalam mengikuti irama, nada serta mengajarkan anak untuk menghargai hasil karya yang dibuatnya.

\section{Memberikan Anak Kebebasan Atau Tidak Terlalu Ikut Campur}

Berbicara mengenai membiasakan anak dalam memecahkan masalah secara mandiri tentu hal ini tidak terlepas dari membiasakan anak untuk mandiri. Menurut Bathi dalam Rika (2017) mengemukakan bahwa kemandirian adalah suatu prilaku atau aktivitas yang sifatnya lebih mengarah pada dirinya sendiri, tidak terlalu mengharapkan bantuan orang lain, dan selalu berusaha untuk dapat memecahkan masalahnya sendiri. Hal senada disampaikan oleh Komala (2015) bahwa kemandirian meliputi kemampuan berinisiatif, mampu menyelsaikan masalah-masalah, memiliki rasa percaya diri dan dapat melakukan dengan diri sendiri tanpa membutuhkan orang lain.

Menurut salah satu informan ibu A (31) mengatakan bahwa mengajarkan anak terampil dalam memecahkan masalah dengan mandiri sama halnya mengajarkan anak untuk berlaku mandiri dalam kehidupannya. Menurutnya mandiri diartikan sebagai salah keterampilan anak dalam menyelsaikan masalahnya serta mampu melakukan hal yang dibutuhkan sendiri tanpa memerlukan bantuan dari orang lain. Selain itu Ibu DN (29) mengungkapkan bahwa mengajarkan anak dalam memecahkan masaalah hendaknya dimulai sejak dini agar anak menjadi mandiri dan tidak tergantung kepada orang lain. Menurutnya untuk melatih anak mandiri dapat dilakukan dengan memberikan kepercayaan serta kebebasan dalam kegiantannya. Jangan sampai selaku orangtua terlalu ikut campur terhadap apa yang menjadi kegiatannya. Hal ini juga dikatakan oleh Erikso dalam teori perkembangan psikososialnya membagi perkembangannya menjadi empat tahap, salah satunya ialah tahapan Autonome VS Shame/Doubt dimana rasa kemandirian anak dapat dilihat dari kebebasan anak untuk berekspresi sesuai dengan keinginannya, memberi waktu luang untuk melakukan kegiatan ataupun aktifitas dengan sendirinya tanpa dikritik.

Selain itu menurut Rika (2017) dalam membiasakan anak untuk berprilaku mandiri hendaknya untuk mengetahui aspek-aspek kemandirian anak diantaranya ialah meberikan kebebasan kepada anak dan kepercayaan kepada anak. Pertama, memberikan anak kebebasan merupakan hak bagi setiap anak. Anak akan tertekan serta merasa kesulitan apabila tanpa kebebasan. Perwujudan kemandirian anak 
dapat dilihat dari kebebasan dalam mengambil keputusan pada saat menghadapi persoalan. Kedua, memberikan anak kepercayaaan yang dapat membuatnya percaya diri. Percaya diri merupakan sikap atau prilaku individu yang memperlihatkan keyakinan bahwa dirinya dapat mengembangkan rasa dihargai. Hal yang bisa dilihat dari memberikan kepercayaan diri pada anak ialah kemampuan anak berani dalam memilih serta kemampuannya dalam mengorganisasikan diri dengan baik sehingga dapat memunculkan sesuatu hal yang sifatnya bagus.

\section{KESIMPULAN}

Berdasarkan paparan diatas dapat dikatakan bahwa pemecahan masalah merupakan suatu proses atau cara yang dilakukan oleh invidu untuk mencari dan menemukan jalan keluar dari suatu permasalahan yang dihadapinya. Adapun tujuan dari pembelajaran pemecahan masalah ialah memungkinkan anak untuk lebih analitis dalam mengambil keputusan dalam hidupnya.serta membiasakan anak agar menjadi terampil dalam mengolah informasi yang diterimanya, meningkatkan potensi intelektual anak serta mengajarkan anak bagaimana melakukan penemuan berdasarkan proses-proses yang ada agar anak mampu dalam menyelsaikan masalahnya. Selanjutnya berdasarkan hasil penelitian yang telah peneliti lakukan terkait dengan pola pembiasaan pemecahan masalah bagi anak usia dini dilingkungan keluarga sebagaimana yang telah dipaparkan diatas dapat dikatakan bahwa terdapat beberapa pola pembiasaan yang dilakukan oleh orangtua ataupun keluarga di Desa Pejanggik untuk membiasakan anaknya agar terampil dalam memecahkan masalah dalam kehidupannya diantaranya ialah (1) Memberikan anak rasa nyaman, (2) Mengetahui prinsip perkembangan anak, (3) Membangun komunikasi dengan baik, (5) Memberikan teladan, (6) Mengasah kemampuan anak, (7) Memberikan kebebasan atau tidak ikut campur, (8) Memberikan anak kebebasan atau tidak terlalu ikut campur. Melalui penelitian ini maka diharapkan dapat membantu para orangtua ataupun keluarga untuk mengetahui hal-hal yang bisa dilakukan untuk membiasakan anak dalam mengajarkan anak memecahkan masalah secara mandiri dilingkungan keluarga.

\section{DAFTAR PUSTAKA}

Aip Sripudin. (2019). Analisis Tumbuh Kembang Anak Ditinjau Dari Aspek Perkembangan Motorik Kasar Anak Usia Dini. Jurnal EQUILITA. Vol. 1 Isuune 1, 2019.

Asti Inawati. (2017). Strategi Pengembangan Moral dan Agama Untuk Anak Usia Dini. Al-Atfal Jurnal Pendidikan Anak. Vol 3 No.1 2017.

Aswasulasikin, A., Dwiningrum, S. I. A., \& Sumarno, S. (2015). TUAN GURU SEBAGAI TOKOH PEMBANGUNAN PENDIDIKAN DI PEDESAAN. Jurnal Pembangunan Pendidikan: Fondasi dan Aplikasi, 3(1), 1-10. 
Azizah \& Maulina Ezard. (2017). Peran Orang Tua Dalam Mendidik Anak Sejak Dini Di Lingkungan Keluarga. Jurnal Thufula, Vol. 5, No 2 Juli-Desember 2017.

Dewi Sutina, Wusono Indarto, \& Febrialismanto. (2016). Efect Of Mothod of Problem Solving Skills Of Science In Children Aged 5-6 Years In TK AlMunawwarah Merbau By District Belitung Merani Islands. Jurnal Online Mahasiswa FKIP. Vol. 3, No 2, 2016.

Dewi, A. R. T. (2018). Pengaruh Keterlibatan Orangtua Terhadap Perilaku Sosial Emosinal Anak. Jurnal Golden Age, 2(02), 66-74.

Diana Habibatul R. Marjiono \& Deditiani Tri Indrianti. (2017). Hubungan Antara Pola Komunikasi Keluarga Dengan Perkembangan Sosial Emosional Anak Usia Dini Di PAUD Catelya 62 Di Kabupaten Jember. Jurnal Learning Community: Pendidikan Luar Sekolah. 1 (2), 2017.

Erma Widiastuti, Made Tegeh, \& Putu Rahayu. (2018). Pengaruh Pendekatan Saintifik Terhadap Kemampuan Pemecahan Masalah Pada Anak Kelompok B Di Taman Kanak-Kanak. E-Journal Pendidikan Anak Usia Dini Universitas Pendidikan Ganesha. Vol. 6, No 22018.

Ernawulan Syaodih, Ocih Setiasih, Nur Faizah Romadona, \& Hany Handayani. (2018). Pengembangan Kemampuan Pemecahan Masalah Anak Usia Dini Dalam Pembelajaran Proyek Di Taman Kanak-Kanak. Jurnal Pendidikan Anak Usia Dini. vol. 12 Edisi 1, April 2018.

Farida Nur Utami, \& Ratna Wahyu Pusari. (2018). Jurnal AUDI. Vol. 3, No 2 2018.

Holis, A. (2017). Belajar Melalui Bermain untuk Pengembangan Kreativitas dan Kognitif Anak Usia Dini. Jurnal Pendidikan UNIGA, 10(1), 23-37.

Husnul Bahri. (2018). Strategi Komunikasi Terhadap Anak Usia Dini. Jurnal Nuansa. Vol. 11, No 1, Juni 2018.

Husnul Bahri. (2019). Strategi Edutaiment Berbasis Perkembangan Anak Usia Dini. Jurnal Nuansa. Vol. 12, No 1, Juni 2019.

Imam Musbikin. (2010). Buku Pintar PAUD. Yogyakarta: Leksana.

Jamiatul Muslimah, dkk. (2020). Pola Asuh Orangtua Dan Perkembangan Moral Anak Di Usia Dini (Studi Kasus Di TK al Ghazali Jl. Raya Kel Kolpjung Kec Pamekesan Kab Pamekasan). Jurnal Kiddo:Jurnal Pendidikan Anak Usia Dini Vol 1 No 12020.

Jhon Creswell. (2016). Research Design, Pendekatan Metode Kualitatif, Kuantitatif, dan Campuran, terj. Achmad Fawaid dan Rinayati K. Yogyakarta: Pustaka Pelajar.

Khaironi, M. (2017). Pendidikan karakter anak usia dini. Jurnal Golden Age, 1(02), 82-89.

Khotijah, I. (2018). Peningkatan kemandirian anak melalui pembelajaran practical life. Jurnal Golden Age, 2(02), 127-140.

Kiki Suryati. (2019). Meningkatkan Kemampuan Pemecahan Masalah Melalui Metode Mind Map Di Taman Kanak-Kanak Mutiara Merbau Mataram Lampung Selatan. Proposal: Jurusan Pendidikan Anak Usia Dini, FTK, Universitas Islam Raden Lampung. 
Komala. (2015). Mengenal Dan Mengembangkan Kemandirian Anak Usia Dini Melalui Pola Asuh Orang Tua Dan Guru. Jurnal Tunas Siliwangi. Vol. 1, No. 1 Oktober 2015.

Maretha Masyah, Sumarsih, \& Delrefi D. (2017). Jurnal Ilmiah Potensia. Vol. 2, No 2. 2017.

Mariana Ikun R.P, Soemarti Patmodewno \& Arifin Y. (2017). Program Pelatihan Pada Ibu Untuk Meningkatkan Pengetahuan Komunikasi Efektif Anak Prasekolah. Jurnal RAP UNP. Vol. 8 No. 2, November 2017.

Mukhtar Latif, Zukraina, Rita Z, \& m. Afandi (2014). Orientasi Pendidikan Anak Usia Dini Teori dan Aplikasi. Jakarta: Kencana.

Mukti Amini. (2015). Profil Keterlibatan Orang Tua Dalam Pendidikan Anak Usia Dini . Jurnal Ilmiah: VISI PPTK PAUDNI. Vol. 10, No 22018.

Ni Made Ayu Suryaningsih \& Ni Luh Rimpiati. (2018). Implementation Of Game-Based Thematic Science Approach in Developing Early Childhood Cognitive Capabilites. Jurnal Obsesi: Jurnal Pendidikan Anak Usia Dini. Vol. 2 Issue 22018.

Novrida \& Nira Kurniah. (2017). Peran Orang Tua Dalam Pendidikan Anak Usia Dini Ditinjau dari Latar Belakang Pendidikan. Jurnal Potensia: $P G$ PAUD, FKIP UNIB. Vol. 2, No 12017.

Rahimnur Diadha. (2015). Keterlibatan Orang Tua Dalam Pendidikan Anak Usia Dini Di Taman Kanak-Kanak. Jurnal Edusentris: Jurnal Ilmu Pendidikan dan Pengajaran. Vol. 2, No 1, Maret 2015.

Rika Sa'diyah. (2017). Pentingnya Melatih Kemandirian Anak. Jurnal Kordinat. Vol. XIV, No 1. April 2017. (2013). Bandung: PT. Rosdakarya.

Sugiyono. (2016). Metode Penelitian \& Pengembangan Research and Development. Bandung: Alfabeta.

Suyadi \& Malidya Ulfah. (2013). Konsep Dasar PAUD. Bandung: PT. Rosdakarya.

Tri Endang Jatmikowati. (2018). Efektifiitas Komunikasi Orangtua Terhadap Kepribadian Interpersonal Anak. PEDAGOGI: Jurnal Anak Usia Dini dan Pendidikan Anak Usia Dini. Vol. 4, No 2, Agusutus 2018.

Wardatul Asyifah \& Lailul Ilham. (2019). Jurnal Hisbah: Jurnal Bimbingan Konseling dan Dakwah Islam. Vol. 16, No 1, Juni 2019.

Wahyuni, S., \& Efastri, S. M. (2019). Pendekatan Behavioral (Teknik Reinforcement) Untuk Meningkatkan Perilaku Prososial Anak Usia 5-6 Tahun Di Tk Aisyiyah Iii Kota Pekanbaru. Jurnal Golden Age, 3(02), 136142.

Yuhasriati \& Dewi Wahyuni. (2016). Mengembangkan Kemampuan Kognitif Anak Melalui Bermain Rancang Bangun Balok Di PAUD IT Al Fatih Kota Banda Aceh. Jurnal Ilmiah Mahasiswa Pendidikan Anak Usia Dini. Vol. 1, No 1, Agustus 2016.

Yupit Yulianti. (2017). The Parenting In Forming Morality Behavior Of Teenager (Case Study Student In Senior High School Tuah Kemuning Kemuning Sub-district Indagiri Hilir District). Jurnal Jom FISIP. Vol 4, No. 2 Oktober 2017. 